\title{
Monitoring blackleg (Leptosphaeria spp.) ascospore release timing and quantity enables optimal fungicide application to improved oilseed rape yield and seed quality
}

\author{
A. Brachaczek • J. Kaczmarek • M. Jedryczka
}

Accepted: 24 March 2016 / Published online: 2 April 2016

(C) The Author(s) 2016. This article is published with open access at Springerlink.com

\begin{abstract}
Stem canker is a damaging disease of winter oilseed rape, caused by ascomycetous fungi Leptosphaeria maculans and L. biglobosa. The initial source of plant infection is ascospores, formed in pseudothecia on stubble from the previous growing season. The aim of this work was to evaluate the effectiveness of fungicide treatments at different times of application in the autumn on quality and quantity of seed yield, in relation to the concentration of ascospores of L. maculans and L. biglobosa in the air. Field experiments were done in Lower Silesia, the region of intensive oilseed rape cultivation, located in south-west Poland. We have demonstrated that, in case of high disease pressure, fungicide treatment against stem canker was most efficient when done 4-11 days after the highest concentration of pathogen ascospores in air. The seed yield, oil and protein content increased by $17.7-$ $18.8 \%, 1.60-1.72 \%$ and $0.8-0.9 \%$ respectively. In low disease pressure the optimal spray time was more flexible, but the highest yield was always following the maximum ascospore release. In some cases it also coincided with the increase of oil, without adverse effect on protein content. Furthermore, it coincided with the increase of indole glucosinolates, such as glucobrassicine and 4-hydroxyglucobrassicine, and - besides one
\end{abstract}

\footnotetext{
A. Brachaczek

DuPont Poland Ltd., Postepu 17b, 02-676 Warsaw, Poland

J. Kaczmarek · M. Jedryczka $(\square)$ Institute of Plant Genetics, Polish Academy of Sciences, Strzeszynska 34, 60-479 Poznan, Poland e-mail: mjed@igr.poznan.pl
}

studied year - it was also connected with decreased amounts of alkenyl glucosinolates. Both Leptosphaeria species were present in air and in infected plants during their vegetation. The ratio between both species depended on seasons; L. maculans prevailed on leaves in the autumn, whereas L. biglobosa dominated on stems before harvest.

Keywords Blackleg $\cdot$ Fungicide $\cdot$ Glucosinolates $\cdot$ Stem canker. Winter oilseed rape

\section{Introduction}

Winter oilseed rape (Brassica napus L.) is widely grown in Poland to obtain vegetable oil for industrial processing of human and animal feed. In recent years, the area under oilseed rape cultivation in Poland has greatly increased; to $900 \mathrm{kha}$ in 2014. As a result, research on the cultivation of oilseed rape has intensified to maximize yield and reduce costs of crop production. One of the components of agricultural technology is the protection of crop plants against fungal diseases. In accordance with the principles of integrated pest management (Directive 2009/128/ EC), the chemical protection of plants should be limited to necessary procedures performed at optimum time intervals.

Among the diseases that affect oilseed rape, one of the most damaging is blackleg or stem canker of brassicas. Considerable yield losses occur every year (Fitt et al. 2006a). The disease is caused by two related 
pathogens: Leptosphaeria maculans and L. biglobosa (Fitt et al. 2006a; Kaczmarek and Jedryczka 2011). In most cases, disease is initiated in the autumn by ascospores originating from fruiting bodies of the sexual stage, produced on oilseed rape stubble from previous seasons (Fitt et al. 2006a). In Canada the dispersal of these pathogens is attributed to pycnidiospores, rather than ascospores (Guo and Fernando 2005). Wind-borne ascospores adhere to the leaf surface and germinate to produce germ tubes, which penetrate the leaf indirectly through stomata or wounds; endophytic mycelia of the pathogens then grow along the leaf petioles asymptomatically to cause lesions on main and branch stems (Hammond et al. 1985). Monitoring of the presence and concentration of fungal spores in air samples makes it possible to identify periods of disease risk to plants (West et al. 2002a; Piliponyte-Dzikiene et al. 2014). The detection of airborne inoculum sources at early stages of plant infection allows to assist in decisions on the optimal time for fungicide application (Gladders et al. 1998). In Poland, such monitoring is done using a network of 10 volumetric spore samplers (Burkard Manufacturing Ltd., Rickmansworth, UK and Lanzoni S.r.l., Italy) within the System for Forecasting Disease Epidemics (Jedryczka et al. 2012). The System has been constantly operating since 2004 as a joint initiative of the Institute of Plant Genetics PAS and DuPont Poland (Jedryczka et al. 2006). It is addressed to oilseed rape farmers, associated farm service personnel, breeders, commercial company representatives as well as to students and researchers with an interest in plant pathology and plant protection. The concentration of Leptosphaeria spp. in air samples is important information for the control of blackleg of oilseed rape, as the time of peak ascospore numbers greatly differs from year to year and between the regions. The output information of the System is distributed in three ways: via website, SMS text messages and emails to registered users. The data are published at the educational website of the Institute (www.spec.edu.pl) and a commercial site owned by DuPont Poland, www.dupont.pl (Jedryczka et al. 2006). Similar studies were also done in Lithuania (Brazauskiene and Petraitiene 2006) as well as in the Czech Republic (Jedryczka et al. 2010). Ascospores of L. maculans and L. biglobosa in air samples were being trapped using volumetric spore samplers and then quantified with light microscopic and molecular techniques (Jedryczka et al. 2010; Kaczmarek et al. 2012; Piliponyte-Dzikiene et al. 2014).
There are many studies connected with the effectiveness of fungicides in relation to various fungal diseases (West et al. 2002a; Brazauskiene and Petraitiene 2004; Steed et al. 2007; Karolewski et al. 2009), but knowledge regarding their influence on plant physiology and quality of harvested seeds is poor. Most studies focused on the impact of single applications of fungicides on yield, but they have not examined in detail the relationship between fungicide treatment and plant health, seed yield and their quality in relation to spore concentration in the air. Some authors have demonstrated that interaction of the members of Brassicaceae with their microbial and fungal pathogens affected the content and biological activities of glucosinolates and their catabolites (Giamoustaris and Mithen 1995; Manici et al. 1997). On the other hand, Andreasson et al. (2001) showed that the growth of $L$. maculans in plant tissues did not alter glucosinolate levels, suggesting the fungus does not degrade these compounds.

The current investigation was part of a study undertaken to improve the efficiency of the decision support system, developed to optimize fungicide treatments to control stem canker of oilseed rape in the region of its intensive cultivation in Poland. The study was carried out to determine the relationship between fungicide applications in the autumn, the concentration of L. maculans and L. biglobosa ascospores in air and the incidence of stem canker before harvest. We have also studied the impact of fungicide treatments on yield and quality of oilseed rape seeds in relation to fungicide spray time.

\section{Materials and methods}

\section{Experiment site}

The research was conducted at the Experimental Station for Variety Testing in Kroscina Mala (N51 ${ }^{\circ} 22$ '29.0", E16 56'38.0") in Lower Silesia, located in south-west Poland. The experiment lasted four vegetative seasons, from 2009/2010 to 2012/2013.

Ascospore trapping method

Monitoring of the concentrations of $L$. maculans and L. biglobosa ascospores was carried out using a Burkard 7-day recording spore sampler (Burkard Manufacturing Co., Rickmansworth, UK) (Fig. 1a). The source of 
Fig. 1 Hirst-type spore trap used in the experiment (a) and the disease symptoms on oilseed rape: leaf spotting (autumn, before winter pause), stage 3 (b); upper stem lesions (summer, before harvest), stages 8-9 (c); cross-section of stems with blackleg symptoms (summer, before harvest), stages 3-4 (d)
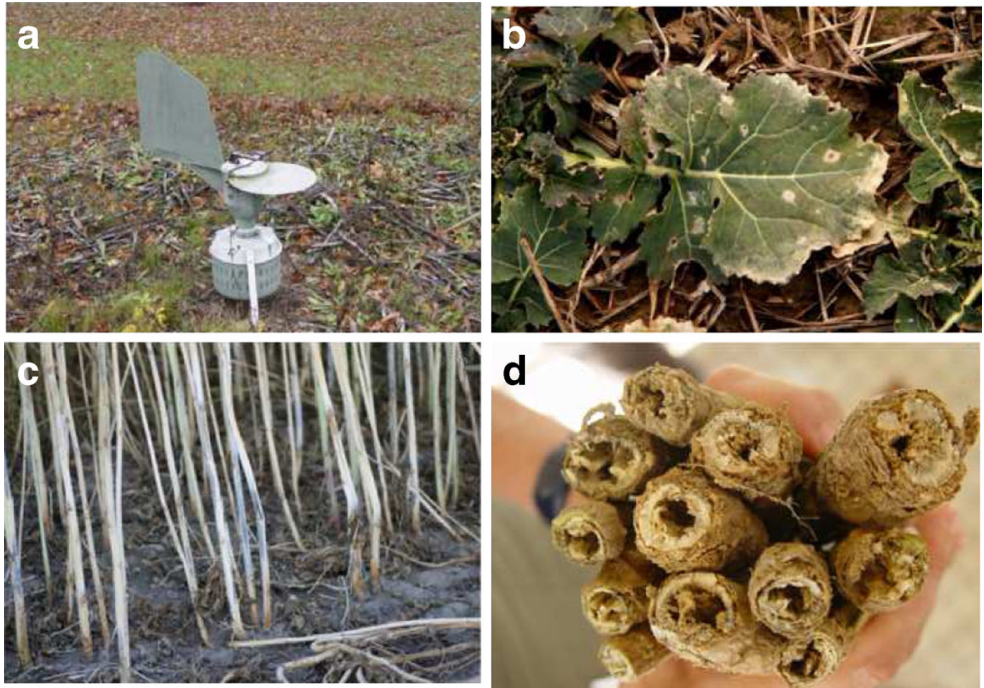

spores was natural release from winter oilseed rape stubble incubated in the surroundings of the trap, as well as all other sources available in the region. The stubble of winter oilseed rape was collected from local fields, after crop harvest in July 2009-2011. The methods used in this experiment were based on these described by Lacey and West (2006). The suction power of the sampler was $10 \mathrm{~L}$ of air $\min ^{-1}$ and the particles of aeroplankton were deposited on a Vaseline-coated Melinex tape mounted on a rotating drum. The tape was collected and cut into seven $48 \mathrm{~mm}$ pieces weekly (one piece representing 1 day). Each piece of tape was cut in half lengthwise. One half was mounted onto a microscope slide for counting ascospores. Spore counts were carried out using the whole area of the slide (halftape), with the use of an Axiostar microscope (Zeiss, Germany) under $\times 200$ magnification. The numbers of spores were counted and recorded as daily ascospore number per $\mathrm{m}^{3}$ of air. The second half of the tape was stored at $-20{ }^{\circ} \mathrm{C}$ until DNA extraction.

\section{Field experiment design}

Field experiment was carried out in a close distance from the spore sampler in a randomized complete block design with 3 replicates. A fully restored winter oilseed rape hybrid cultivar PR46W10 F1 (Pioneer Hi-Bred) was sown at the end of August. Plot size was $15 \mathrm{~m}^{2}$. Fungicide treatments were done at weekly intervals from late September to mid-November, with the fungicide Capitan $250 \mathrm{EW}$, containing $250 \mathrm{~g} \mathrm{~L}^{-1}$ of flusilazole, at the dose of $0.5 \mathrm{~L} \mathrm{ha}^{-1}$; each plot was sprayed one time. Disease incidence and severity were assessed in autumn for each variant, on 50 plants per replicate, according to a scale from 0 to 4 , where $0=$ no visible disease symptoms and $4=$ numerous phoma leaf spots on a plant (Fig. 1b). The upper stem lesions, associated with the infection by L. biglobosa, were scored before harvest using 0 to 9 scale, where $0=$ no visible symptoms and $9=$ plant totally damaged by the disease, dry, with large portions of the main and side stems covered with pycnidia (Fig. 1c). The stem canker symptoms (blackleg) were evaluated on cross-sections of plants cut at the stem base, using the scale from $1=$ no visible disease symptoms to $4=$ blackening and disruption of over $75 \%$ of the pith (Fig. 1d). The Disease Index was calculated as described by Lô-Pelzer et al. (2009). All plants with disease symptoms were taken into account, when the disease incidence was calculated.

The percentage of plants with phoma leaf spotting in the autumn, and the percentage of plants with stem cankers before harvest were evaluated. The other measurements included seed yield and the mass of one thousand seeds at $90 \%$ of dry matter content. Oil content was evaluated with the Soxhlet method (Luque de Castro and García-Ayuso 1998) and the total content of proteins was based on the nitrogen content, evaluated with the Kjeldahl method (Kjeldahl 1883) with amendments of Sáez-Plaza et al. (2013). Individual glucosinolates were determined by near-infrared reflectance spectroscopy (NIRS) (Michalski and Czernik-Kolodziej 2000). 
Characterization of the pathogen population

The pathogens were obtained from plots without fungicide treatments. The assessments were made on leaves in the autumn (before winter pause) and then on stem fragments after harvest. The samples were randomly chosen, packed into separate bags and then transported to the laboratory. Fungal strains were isolated by dissecting small infected fragments after surface disinfection of the studied plant organ (leaf or stem base). The isolates were subcultured on PDA medium supplemented with $1 \%$ streptomycin sulphate (Sigma-Aldrich) until they were free from bacteria. To ensure the genetic identity of studied fungal isolates, subcultures on new growth medium were started from hyphal tips. The classification to the appropriate species of the Leptosphaeria complex (L. maculans or L. biglobosa) was based on the cultural characteristics, as described by Kaczmarek and Jedryczka (2011).

DNA extraction from spore samples and real-time PCR conditions

DNA was extracted from the tape pieces using a CTAB (hexadecyltrimethylammonium bromide) protocol, as described by Kaczmarek et al. (2009). One half of the tape was placed in a sterile $2 \mathrm{ml}$ tube with acid-washed glass beads of particle sizes ranging from 425 to $600 \mu \mathrm{m}$. Then, $2 \%$ CTAB buffer was added and tubes were shaken in a Fast-Prep machine (Savant Instruments, USA) twice for $40 \mathrm{~s}$. Afterwards, the samples were incubated for $30 \mathrm{~min}$ at $70^{\circ} \mathrm{C}$, centrifuged for $15 \mathrm{~min}$ and an equal volume of a chloroform:isoamyl alcohol mixture (24:1) was added. DNA was precipitated by incubation for $1 \mathrm{~h}$ at $-20{ }^{\circ} \mathrm{C}$ with absolute ethanol and sodium acetate $(3 \mathrm{M})$ and then centrifuged for $15 \mathrm{~min}$. The supernatant was discarded and DNA pellets were washed with $70 \%$ ethanol, dried, and dissolved in $100 \mu \mathrm{l}$ of TE (Tris-EDTA) buffer. For real-time PCR analysis, a $10 \mu \mathrm{L}$ reaction contained $2.5 \mu \mathrm{L}$ (1:4 aqueous dilution) of DNA template, $0.3 \mu \mathrm{L}$ of each L. maculans or L. biglobosa species specific primers (Mahuku et al. 1996), $5 \mu$ l of SYBR Green JumpStart Taq ReadyMix (Sigma-Aldrich, UK), $1.9 \mu \mathrm{L}$ of nuclease-free sterile water. Cycling parameters consisted of $95{ }^{\circ} \mathrm{C}$ for $2 \mathrm{~min}, 95^{\circ} \mathrm{C}$ for $15 \mathrm{~s}, 60^{\circ} \mathrm{C}$ for $30 \mathrm{~s}, 72^{\circ} \mathrm{C}$ for $45 \mathrm{~s}, 38$ cycles in total. A standard curve was generated by plotting the threshold cycle $\left(C_{t}\right)$ value for each sample of a standard series of $L$. maculans and
L. biglobosa DNA concentrations from $10 \mathrm{ng} \mu \mathrm{L}^{-1}$ to $100 \mathrm{fg} \mu \mathrm{L}^{-1}$. Nuclease-free water was used as notemplate control.

Molecular identification of Leptosphaeria species on plants

The 632 isolates obtained in this study (40 per the combination of crop stage $\times$ year) were first classified as L. maculans or L. biglobosa based on culture morphology and macroscopic identification. The classifications were confirmed on a subset of 120 randomly selected isolates using Random Amplified Polymorphic DNA (RAPD).

For PCR, genomic DNA was extracted from freezedried mycelium using the CTAB. Mycelia were ground in $650 \mu \mathrm{L}$ CTAB extraction buffer with $\mathrm{SiC}$ and incubated at $65^{\circ} \mathrm{C}$ for $20 \mathrm{~min}$. An aliquot of $500 \mu \mathrm{L} \mathrm{CHCl}_{3}$ was added to the tube and centrifuged at $9000 \mathrm{rpm}$ for $15 \mathrm{~min}$. DNA was precipitated with $65 \mu \mathrm{L} 3 \mathrm{M}$ sodium acetate, $\mathrm{pH} 5.4$, and two volumes of ice cold $99.8 \%$ ethanol. The Eppendorf tubes were stored at $-20{ }^{\circ} \mathrm{C}$ overnight and centrifuged at 15,000 rpm for $5 \mathrm{~min}$. The resulting pellets were washed with $70 \%$ ethanol, centrifuged at $15,000 \mathrm{rpm}$ for $5 \mathrm{~min}$, and fully dissolved in $100 \mu \mathrm{L}$ TE buffer.

RAPD amplification was carried out in a $10 \mu \mathrm{L}$ volume containing: $1 \mu \mathrm{L}$ DNA, $0.2 \mathrm{mmol}$ dNTPs, $1 \mathrm{mmol} \mathrm{MgCl}_{2}, 1 \mu \mathrm{mol}$ of the primer OPJ-10 (AAGCCCGAGG), 0.5 U DNA Taq polymerase (DreamTaq ${ }^{\mathrm{TM}}$ DNA Polymerase, Thermo Scientific), $1 \mu \mathrm{L}$ buffer $\left(10 \times\right.$ with $\left.\mathrm{Mg}^{2+} 2 \mathrm{mmol}\right)$, and sterilized water to the total volume of $10 \mu \mathrm{L}$. PCR amplification conditions for RAPD were as follows: one cycle of 2 min at $94{ }^{\circ} \mathrm{C}$ (initial denaturation), followed by $45 \mathrm{cy}-$ cles of $30 \mathrm{~s}$ at $94{ }^{\circ} \mathrm{C}$ (denaturation), $1 \mathrm{~min}$ at $36{ }^{\circ} \mathrm{C}$ (annealing) and $2 \mathrm{~min}$ at $72^{\circ} \mathrm{C}$ (extension). A final step of 5 min at $72{ }^{\circ} \mathrm{C}$ ensured full extension of all amplified products.

PCR products were separated on a $1.5 \%$ agarose gel, stained with ethidium bromide and visualized with a UV transilluminator. The bands were compared with the specific banding patterns characteristic for the representatives of two Leptosphaeria species, previously recognised for both species.

Statistical analysis

Statistical analysis was carried out using Statistica version 7.0 (StatSoft Inc., USA) and Microsoft Excel 
version 2010 (Microsoft, Inc., USA). Inference about the significance of differences between objects was conducted using one way ANOVA and was determined using Tukey's test $(p \leq 0.05)$. For the analysis of variance, the percent of infected plants was transformed using the formula and table elaborated by Bliss (1938).

\section{Results}

Concentration of ascospores of Leptosphaeria spp.

The ascospores of Leptosphaeria spp. were observed in the air in each of the studied autumn periods (20092012). The date of the beginning and the end of the season differed between seasons - the earliest ascospore release was observed on 5 September (2012) and the latest start of the ascospore season was on 15 September (2010 and 2011). The difference between the ends of the season was 8 days and ranged from 15 November to 23 November. The sum of daily spore concentrations in air samples differed between the subsequent autumn periods; in 2010 there were 246 ascospores per $1 \mathrm{~m}^{3}$ (Table 1), but in 2012 the concentration of ascospores increased two-fold. The highest peak of ascospores in $1 \mathrm{~m}^{3}$ of air ranged from 30 (27 September 2010) to 58 ascospores (22 September 2011). The peak days with maximal ascospore numbers in air samples differed by 2 weeks; they could be present as early as 22 September (2011) and as late as 6 October (2012). The highest concentration of ascospores in air samples was highly correlated with the cumulative number of daily mean ascospore concentrations (0.86).

Composition of the pathogen population in air samples

The visual observation of ascospores in the air does not allow identification of the species, so the microscopic analyses were supplemented with molecular detection of DNA of L. maculans and L. biglobosa. The proportion of species ranged from 1:2 (2011) to 1:33 (2009) (Fig. 2). The range of DNA concentrations was from $413 \mathrm{pg} \mu \mathrm{L}^{-1}$ (2010) to $2579 \mathrm{pg} \mathrm{\mu L}^{-1}$ (2012) of

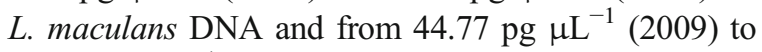

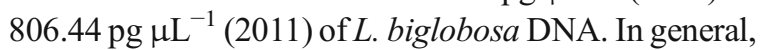
in the autumn, L. maculans DNA was detected on $40 \%$ more days than $L$. biglobosa DNA. The species were observed both together and on different days. The percent of days when DNA of L. maculans and L. biglobosa was found together varied from $5.5 \%$ (2010) to $14.3 \%$ (2011). The highest concentrations of DNA of both Leptosphaeria species were observed mostly on the same days as indicated by microscopic observations (Fig. 2). Results obtained with the molecular detection using quantitative PCR were correlated to the spore counts. The Spearman's rank correlation coefficients were statistically significant and varied from 0.87 (season 2011/2012) to 0.99 (season 2010/2011) (Fig. 3).

Effect of spray time on phoma leaf spotting/stem canker symptoms and seed quantity and quality

The timing of fungicide application had a significant effect on the severity of symptoms of phoma leaf spotting and stem canker. In all studied seasons, the lowest percentage of healthy plants was observed on unsprayed plots (Table 2), and varied from $21.35 \%$ (autumn 2009) to $48.8 \%$ (autumn 2010 ) in the autumn and from $18.3 \%$ (summer 2010) to $52.8 \%$ (summer 2011) 2 weeks before harvest. In comparison with fungicide treatments 4-8 days after the highest daily mean ascospore concentration (Table 1), the increase in disease severity symptoms was from 3- to 7-fold in the autumn (2012 and 2009 respectively) and from 2- to 4.6-fold in the summer (2013 and 2010, respectively). Significant differences in the incidence of phoma leaf spotting and stem canker between plants sprayed in various dates also were demonstrated. The sprays late in the season (2-18 November) were the least effective (Table 2). In all seasons, the correlation coefficient between the percentage of plants infected before winter and before harvest was highly significant $\left(\mathrm{R}^{2} \approx 0.95\right)$. The highest yield was obtained when the percentage of infected plants was the lowest. In 2010-2013, the increase in yield in plots treated at the optimal time as compared with control treatments was $5-12.5 \mathrm{dt} \mathrm{ha}^{-1}$. In 2010, 2012 and 2013, the oil content was not altered significantly by application of fungicides. However, in 2011 the increase of this parameter was as high as $7 \%$. Maximum oil accumulation (49.89\%) was recorded from the seeds of those plants that were treated with fungicides 12 days after the occurrence of the highest daily mean concentration of ascospores.

Protein content in the seeds of winter rapeseed ranged from 18.88 to $21.02 \%$. Only in 2010 was the protein content in seeds from plots treated 8 days after 
Table 1 The characterization of the Leptosphaeria spp. ascospore release in autumn 2009-2012, Lower Silesia (Kroscina Mala), Poland

\begin{tabular}{|c|c|c|c|c|}
\hline \multirow[t]{2}{*}{ Month } & \multicolumn{4}{|l|}{ Autumn } \\
\hline & 2009 & 2010 & 2011 & 2012 \\
\hline \multicolumn{5}{|c|}{ Number of days with ascospore detection in the air } \\
\hline September & 18 & 16 & 16 & 25 \\
\hline October & 25 & 15 & 31 & 26 \\
\hline November & 12 & 23 & 12 & 5 \\
\hline Sum of the season & 55 & 54 & 59 & 56 \\
\hline \multicolumn{5}{|c|}{ The highest daily mean concentration of ascospores in $1 \mathrm{~m}^{3}$ of air (date of the detection of maximum spore concentration in the season) } \\
\hline September & 48.61 (29 Sept.) & 29.99 (27 Sept.) & 58.47 (22 Sept.) & 50.69 \\
\hline October & 27.50 & 19.58 & 43.33 & 53.33 (6 Oct.) \\
\hline November & 13.61 & 13.61 & 3.19 & 1.53 \\
\hline \multicolumn{5}{|c|}{ Sum of daily mean ascospore concentration in $1 \mathrm{~m}^{3}$ of air } \\
\hline September & 103.6 & 81.24 & 245.82 & 342.20 \\
\hline October & 194.4 & 79.44 & 211.38 & 189.43 \\
\hline November & 45.6 & 85.27 & 7.36 & 3.61 \\
\hline Sum of the season & 343.6 & 245.96 & 464.55 & 535.24 \\
\hline \multicolumn{5}{|c|}{ Mean ascospore concentration in $1 \mathrm{~m}^{3}$ of air } \\
\hline September & 3.45 & 2.71 & 8.19 & 11.41 \\
\hline October & 6.27 & 2.56 & 6.82 & 6.11 \\
\hline November & 1.52 & 2.84 & 0.25 & 0.12 \\
\hline Mean of the season & 3.75 & 2.70 & 5.09 & 5.88 \\
\hline \multicolumn{5}{|c|}{ Date of the first ascospore detection } \\
\hline & 12 Sept. & 15 Sept. & 15 Sept. & 5 Sept. \\
\hline \multicolumn{5}{|c|}{ Date of the last ascospore detection in the autumn } \\
\hline & 15 Nov. & 23 Nov. & 20 Nov. & 16 Nov. \\
\hline
\end{tabular}

detection of the maximum ascospore concentration of ascospores significantly higher than in seeds from untreated plots. In this year also, an increased thousand seed mass was found as a result of the optimal application of the fungicide. It was $0.4 \mathrm{~g}$ higher than in untreated plots (Table 2).

Fungicide treatments had an effect on the amount of glucosinolates in harvested seeds. They contained significantly more indole glucosinolates and less alkenyl glucosinolates in most variants treated with flusilazole. In the case of indole glucosinolates the effect included glucobrassicine and 4-hydroxyglucobrassicine. The highest level of glucobrassicine was found after treatment on 7 October 2009, representing an 8-fold increase compared with the control. The level of 4hydroxyglucobrassicine was higher in nearly all sprayed plots as compared to control, with the exception of seeds harvested in 2013 (Table 3). The highest increase of 4- hydroxyglucobrassicine was 2-fold and it was found in seeds sprayed with flusilazole on 19 October 2012. Fungicide treatment coincided with the lower content of alkenyl glucosinolates as compared to the control. The levels of gluconapine, glucobrassicanapine, napoliferine and progoitrine were significantly lower in unsprayed variants, with the exception of seeds harvested in 2011.

Pathogen population study

In the autumn, L. maculans was predominant on leaves of oilseed rape and constituted $83.0 \%$ of the Leptosphaeria population on average. Each summer, the dominant species was L. biglobosa, and it was reisolated from $75.4 \%$ of stem canker symptoms on stems (Table 4). Generally, in the autumn, the ratio of L. maculans: L. biglobosa isolates obtained from 


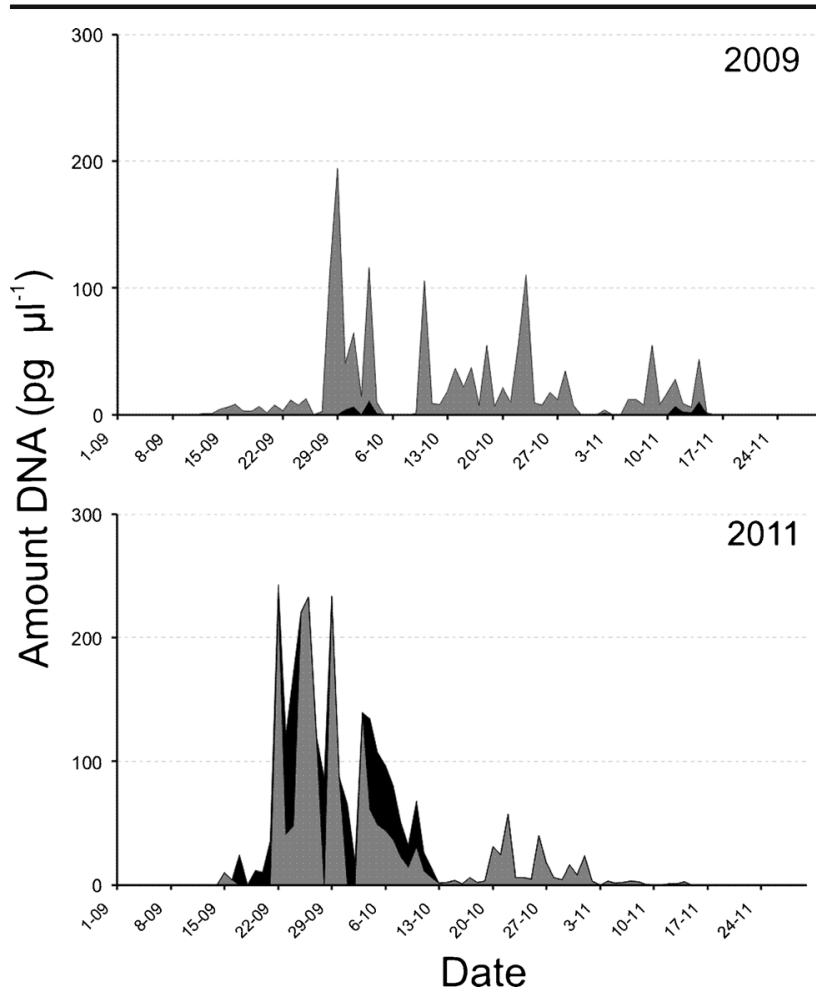

Fig. 2 Seasonal fluctuations in the quantities of DNA obtained by sampling airborne propagules of Leptosphaeria maculans (grey bar) and L. biglobosa (black bar) over four consecutive autumn

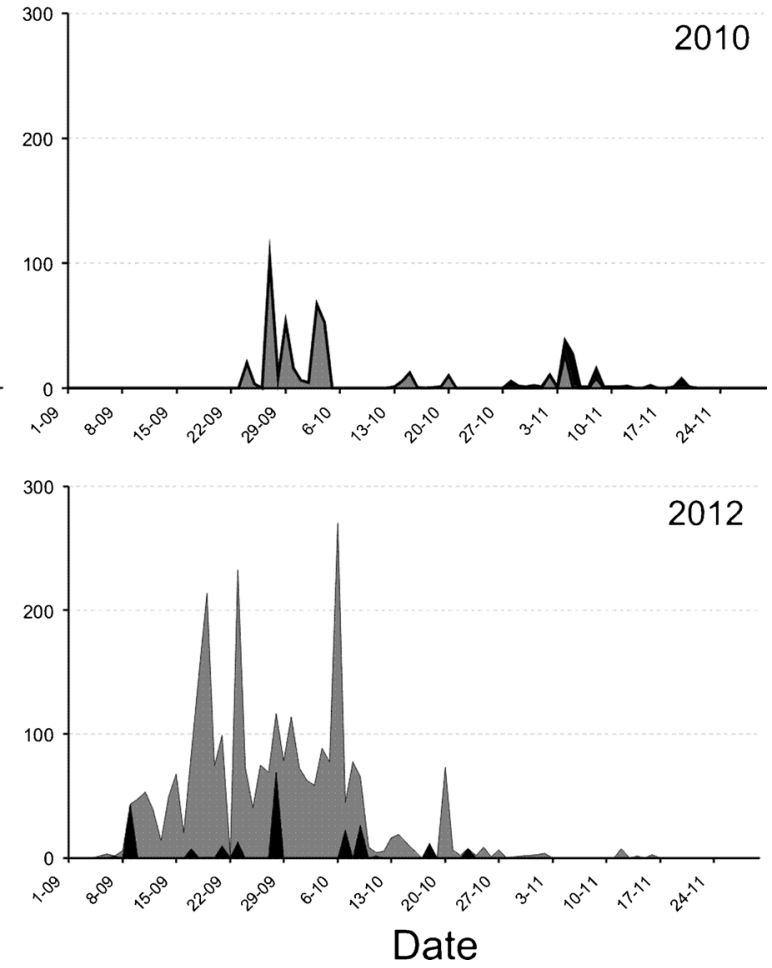

(September to November) periods (2009-2012) in samples collected by a Burkard spore trap located in Lower Silesia (Kroscina Mala), Poland
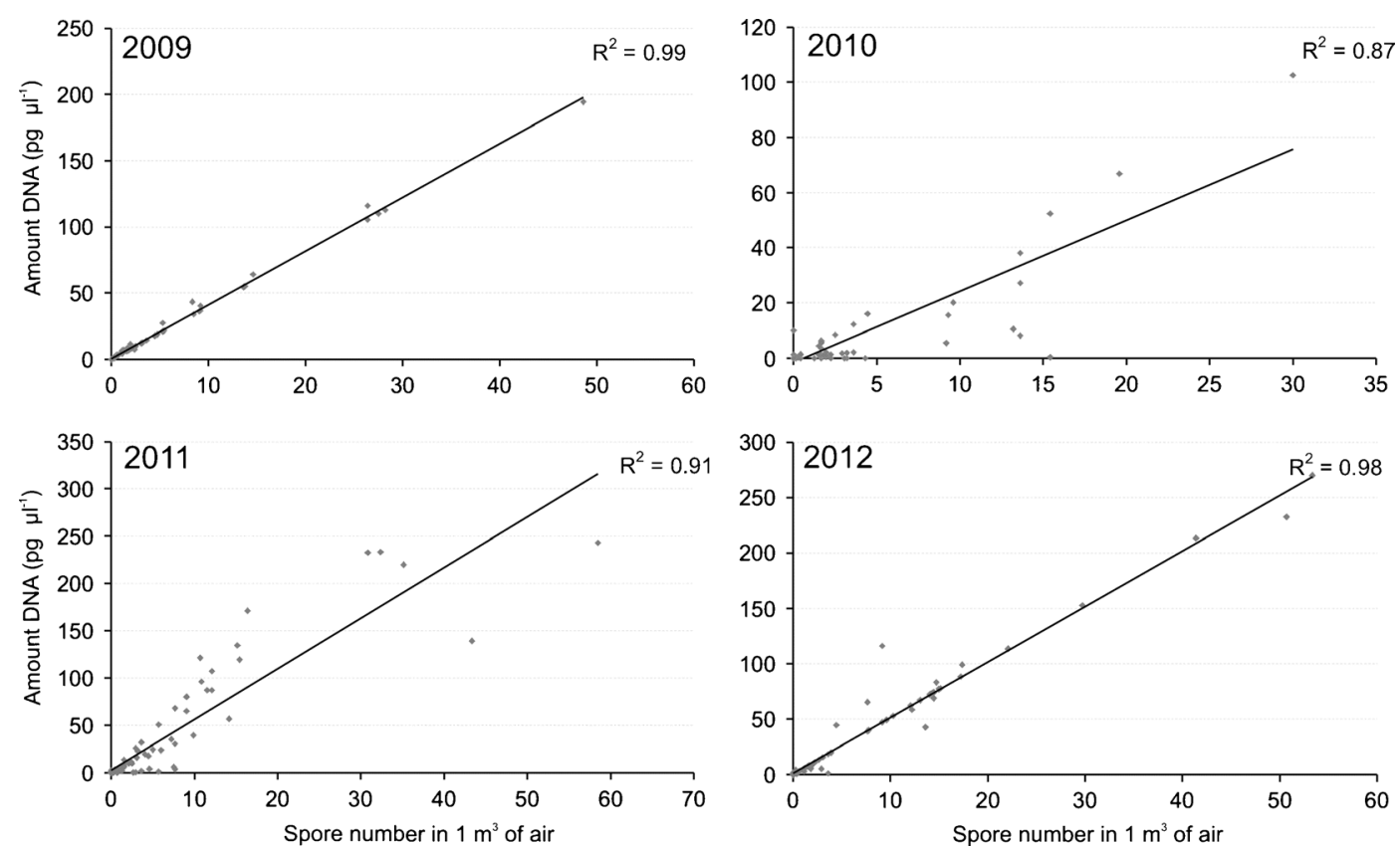

Fig. 3 Correlation between the number of Leptosphaeria spores $\mathrm{m}^{-3}$ and the summary amount of DNA of L. maculans and L. biglobosa $\left(\mathrm{pg} \mu \mathrm{l}^{-1}\right)(2009-2012)$ 
Table 2 The effect of fungicide application time on plant health, seed yield quantity and quality of oilseed rape cv. PR46W10 F1, in 20102013, Lower Silesia, Poland

\begin{tabular}{|c|c|c|c|c|c|c|}
\hline Date of treatment & Infected plants $(\%)$ & & Oil content $(\%)$ & Protein content $(\%)$ & Mass of thousand seeds ( $\mathrm{g}$ ) & Yield $\left(\mathrm{dt} \mathrm{ha}^{-1}\right)$ \\
\hline $2009 / 2010$ & Autumn $^{\mathrm{a}}$ & Summer $^{\mathrm{b}}$ & & & & \\
\hline 30 Sept. & $9.09 \mathrm{~b}$ & $6.73 \mathrm{c}$ & $48.92 \mathrm{a}$ & $19.50 \mathrm{ab}$ & $3.82 \mathrm{ab}$ & $42.00 \mathrm{c}$ \\
\hline 07 Oct. & $3.01 \mathrm{a}$ & $4.01 \mathrm{a}$ & $48.79 \mathrm{a}$ & $19.70 \mathrm{~b}$ & $3.78 \mathrm{ab}$ & $42.00 \mathrm{c}$ \\
\hline 14 Oct. & $8.07 \mathrm{~b}$ & $8.67 \mathrm{~cd}$ & $48.92 \mathrm{a}$ & $19.33 \mathrm{ab}$ & $3.74 \mathrm{a}$ & $42.00 \mathrm{c}$ \\
\hline 22 Oct. & $6.43 \mathrm{~b}$ & $5.42 \mathrm{ab}$ & $49.22 \mathrm{a}$ & $19.12 \mathrm{a}$ & $3.90 \mathrm{~b}$ & $42.00 \mathrm{c}$ \\
\hline 28 Oct. & $7.92 \mathrm{~b}$ & $5.71 \mathrm{ab}$ & $48.74 \mathrm{a}$ & $19.10 \mathrm{a}$ & $3.84 \mathrm{a}$ & $37.67 \mathrm{a}$ \\
\hline 5 Nov. & $12.54 \mathrm{c}$ & $10.56 \mathrm{de}$ & $48.65 \mathrm{a}$ & $19.34 \mathrm{ab}$ & $3.74 \mathrm{ab}$ & $37.00 \mathrm{a}$ \\
\hline 13 Nov. & $12.88 \mathrm{c}$ & $12.88 \mathrm{e}$ & $48.61 \mathrm{a}$ & $19.40 \mathrm{ab}$ & $3.8 \mathrm{ab}$ & $41.03 \mathrm{bc}$ \\
\hline 18 Nov. & $15.84 \mathrm{~d}$ & 10.99 de & $48.11 \mathrm{a}$ & $19.10 \mathrm{a}$ & $3.8 \mathrm{ab}$ & $40.00 \mathrm{~b}$ \\
\hline Control & $21.35 \mathrm{e}$ & $18.30 \mathrm{f}$ & $48.92 \mathrm{a}$ & $19.10 \mathrm{a}$ & $3.8 \mathrm{ab}$ & $37.00 \mathrm{a}$ \\
\hline \multicolumn{7}{|l|}{ 2010/2011 } \\
\hline 24 Sept. & $15.59 \mathrm{bc}$ & $18.30 \mathrm{ab}$ & $47.88 \mathrm{a}$ & $19.40 \mathrm{abc}$ & $4.38 \mathrm{bc}$ & $42.20 \mathrm{~d}$ \\
\hline 1 Oct. & $8.13 \mathrm{a}$ & $14.23 \mathrm{a}$ & $49.89 \mathrm{c}$ & $19.80 \mathrm{bc}$ & $4.61 \mathrm{~d}$ & $44.30 \mathrm{e}$ \\
\hline 8 Oct. & $10.84 \mathrm{ab}$ & $18.30 \mathrm{ab}$ & $49.77 \mathrm{bc}$ & $19.90 \mathrm{c}$ & $4.64 \mathrm{~d}$ & $43.90 \mathrm{e}$ \\
\hline 15 Oct. & $18.30 \mathrm{c}$ & $18.63 \mathrm{ab}$ & $48.03 \mathrm{ab}$ & $19.33 \mathrm{abc}$ & $4.44 \mathrm{ce}$ & $41.57 \mathrm{~cd}$ \\
\hline 20 Oct. & $27.78 \mathrm{~d}$ & $18.30 \mathrm{ab}$ & $48.45 \mathrm{abc}$ & $19.12 \mathrm{ab}$ & $4.58 \mathrm{de}$ & $40.90 \mathrm{bc}$ \\
\hline 2 Nov. & $35.92 \mathrm{e}$ & $23.04 \mathrm{c}$ & $48.09 \mathrm{ab}$ & $19.65 \mathrm{abc}$ & $4.26 \mathrm{ab}$ & $40.00 \mathrm{~b}$ \\
\hline 8 Nov. & $35.24 \mathrm{e}$ & $27.11 \mathrm{c}$ & $48.10 \mathrm{ab}$ & $19.34 \mathrm{abc}$ & $4.32 \mathrm{abc}$ & $38.00 \mathrm{a}$ \\
\hline 15 Nov, & $37.95 \mathrm{e}$ & $27.79 \mathrm{c}$ & $48.09 \mathrm{ab}$ & $19.38 \mathrm{abc}$ & $4.34 \mathrm{abc}$ & $40.00 \mathrm{~b}$ \\
\hline Control & $48.80 \mathrm{f}$ & $52.80 \mathrm{~d}$ & $48.17 \mathrm{abc}$ & $19.00 \mathrm{a}$ & $4.21 \mathrm{a}$ & $37.30 \mathrm{a}$ \\
\hline \multicolumn{7}{|l|}{$2011 / 2012$} \\
\hline 27 Sept. & $7.79 \mathrm{a}$ & $9.37 \mathrm{a}$ & $45.10 \mathrm{a}$ & $18.88 \mathrm{a}$ & $5.16 \mathrm{ab}$ & $43.83 \mathrm{~b}$ \\
\hline 4 Oct. & $8.13 \mathrm{a}$ & $9.84 \mathrm{a}$ & $46.10 \mathrm{a}$ & $19.57 \mathrm{a}$ & $5.36 \mathrm{ab}$ & $44.00 \mathrm{~b}$ \\
\hline 11 Oct. & $11.85 \mathrm{a}$ & $13.22 \mathrm{ab}$ & $46.70 \mathrm{a}$ & $19.57 \mathrm{a}$ & $5.58 \mathrm{~b}$ & $42.70 \mathrm{ab}$ \\
\hline 19-Oct & $23.84 \mathrm{~b}$ & $22.37 \mathrm{de}$ & $49.20 \mathrm{a}$ & $20.31 \mathrm{a}$ & $5.42 \mathrm{ab}$ & $43.51 \mathrm{~b}$ \\
\hline 25 Oct. & $32.53 \mathrm{c}$ & $16.27 \mathrm{bc}$ & $48.00 \mathrm{a}$ & $20.65 \mathrm{a}$ & $5.38 \mathrm{ab}$ & $40.78 \mathrm{ab}$ \\
\hline 02 Nov. & $36.71 \mathrm{~cd}$ & $19.55 \mathrm{~cd}$ & $48.80 \mathrm{a}$ & $20.78 \mathrm{a}$ & $4.98 \mathrm{ab}$ & $39.65 \mathrm{ab}$ \\
\hline 08 Nov. & $36.48 \mathrm{~cd}$ & $18.52 \mathrm{~cd}$ & $47.80 \mathrm{a}$ & $20.79 \mathrm{a}$ & $5.18 \mathrm{ab}$ & $38.79 \mathrm{ab}$ \\
\hline 16 Nov. & $36.78 \mathrm{~cd}$ & $25.98 \mathrm{de}$ & $48.60 \mathrm{a}$ & $20.21 \mathrm{a}$ & $4.80 \mathrm{a}$ & $39.17 \mathrm{ab}$ \\
\hline Control & $38.63 \mathrm{~d}$ & $33.55 \mathrm{e}$ & $45.50 \mathrm{a}$ & $20.53 \mathrm{a}$ & $5.40 \mathrm{ab}$ & $36.02 \mathrm{a}$ \\
\hline \multicolumn{7}{|l|}{$2012 / 2013$} \\
\hline 23 Sept. & $15.46 \mathrm{ab}$ & $13.22 \mathrm{a}$ & $44.90 \mathrm{a}$ & $21.02 \mathrm{a}$ & $5.36 \mathrm{ab}$ & $33.12 \mathrm{ab}$ \\
\hline 30 Sept. & $12.31 \mathrm{a}$ & $11.18 \mathrm{a}$ & $45.30 \mathrm{a}$ & $20.66 \mathrm{a}$ & $5.40 \mathrm{ab}$ & $44.00 \mathrm{~cd}$ \\
\hline 7 Oct. & $10.03 \mathrm{a}$ & $11.18 \mathrm{a}$ & $45.90 \mathrm{a}$ & $21.44 \mathrm{a}$ & $5.48 \mathrm{ab}$ & $45.77 \mathrm{~d}$ \\
\hline 15 Oct. & $10.17 \mathrm{a}$ & $10.17 \mathrm{a}$ & $48.22 \mathrm{a}$ & $20.81 \mathrm{a}$ & $5.64 \mathrm{~b}$ & $45.73 \mathrm{~d}$ \\
\hline 21 Oct. & $14.48 \mathrm{ab}$ & $10.19 \mathrm{a}$ & $46.30 \mathrm{a}$ & $20.67 \mathrm{a}$ & $5.60 \mathrm{ab}$ & $45.75 \mathrm{~d}$ \\
\hline 28 Oct. & $20.45 \mathrm{bcd}$ & $18.30 \mathrm{~b}$ & $46.80 \mathrm{a}$ & $20.75 \mathrm{a}$ & $5.26 \mathrm{ab}$ & $43.29 \mathrm{~cd}$ \\
\hline 5 Nov. & $22.37 \mathrm{~cd}$ & $19.57 \mathrm{~b}$ & $47.00 \mathrm{a}$ & 20.46 a & $4.86 \mathrm{a}$ & $38.07 \mathrm{~cd}$ \\
\hline 12 Nov. & $29.86 \mathrm{e}$ & $25.36 \mathrm{c}$ & $47.60 \mathrm{a}$ & $20.65 \mathrm{a}$ & $5.38 \mathrm{ab}$ & $36.49 \mathrm{abc}$ \\
\hline Control & $25.42 \mathrm{de}$ & $23.38 \mathrm{c}$ & $46.10 \mathrm{a}$ & $20.41 \mathrm{a}$ & $5.36 \mathrm{ab}$ & $31.50 \mathrm{a}$ \\
\hline
\end{tabular}

Different letters are used to point out the variants showing significant differences at $\alpha=0.05$

${ }^{a}$ Evaluation of phoma leaf spotting, using 0-4 scale, assessment before winter pause

${ }^{\mathrm{b}}$ Evaluation of symptoms on stems, using 0-9 scale, assessment 2 weeks before harvest 


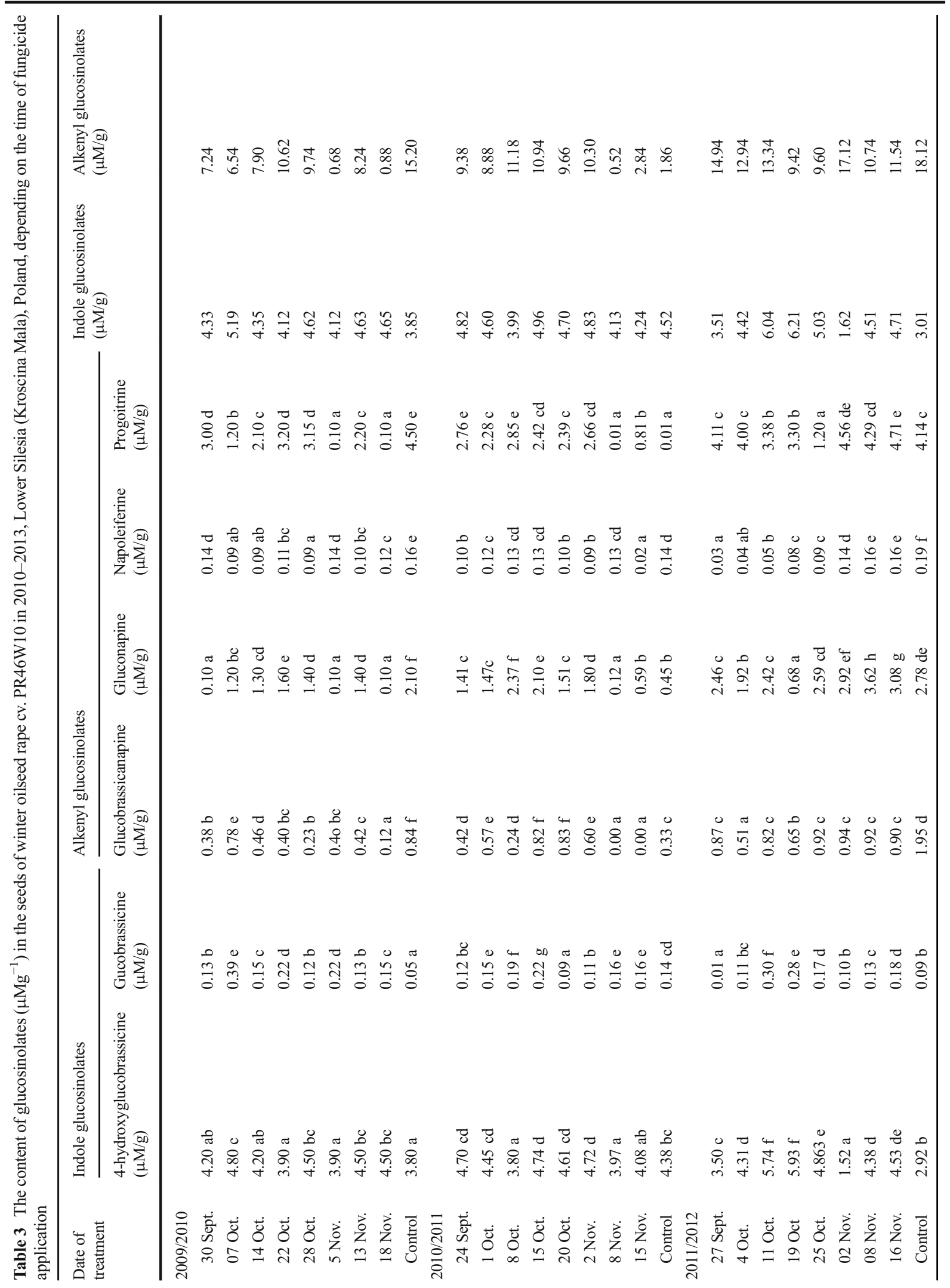




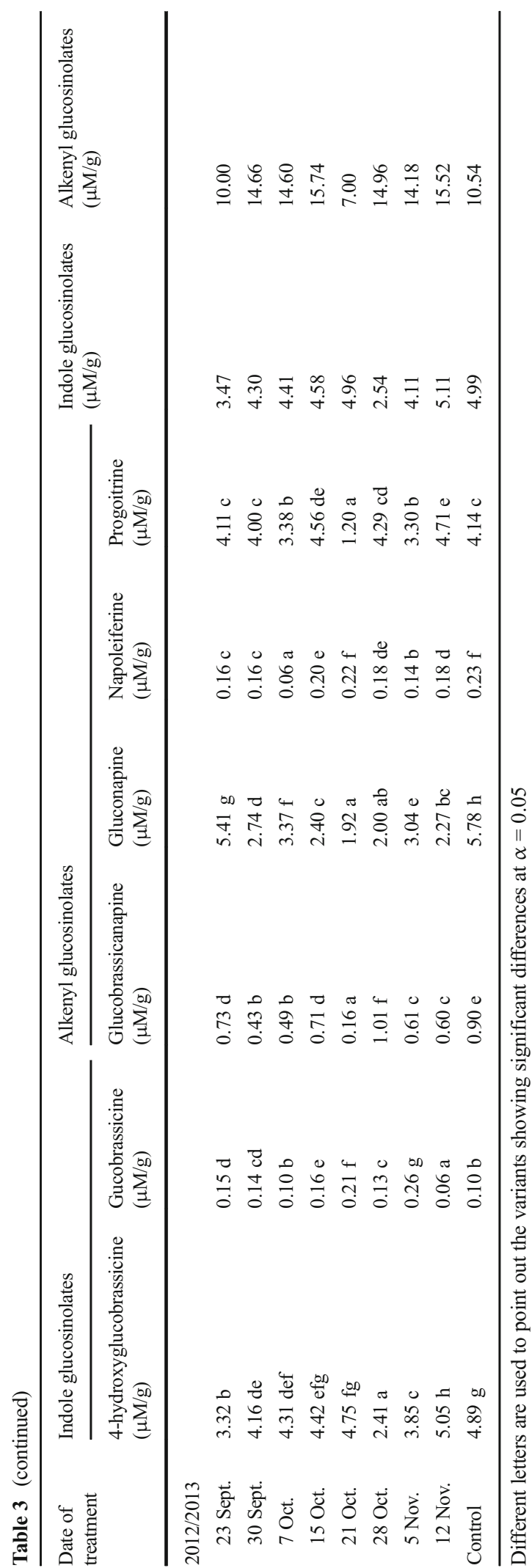

infected leaves was over $4: 1$, while on stems before harvest it was 1:3 (Fig. 4).

\section{Discussion}

This study demonstrated a very strong relationship between the timing of the fungicide treatment and health status of the test plants. We have shown that in case of high disease pressure, fungicide treatment of winter oilseed rape in Lower Silesia was most efficient when it was done 4-11 days after the highest concentration of L. maculans and/or L. biglobosa ascospores in air samples. Moreover, this relationship persisted throughout the growing season until harvest, which indicated that the application of fungicide at optimal time may retard or stop the primary plant infection. Similar results were described in southern England (Sun et al. 2000), north Poland (Kaczmarek et al. 2014) and central Canada (Peng et al. 2015). The fungicide treatment of spring canola in the prairies was efficient only in case of very high disease pressure.

Financial calculations done in our experiments demonstrated that the yield benefit was always higher as compared to the expenditure on fungicide spray, taking into account the cost of the fungicide and its application as well as the workload. In case of prolonged occurrence of high spore concentrations in the autumn one spray may not be sufficient to reduce the pathogen to safe amounts, however the efficiency of two sprays was not studied experimentally.

The quality of rapeseed greatly depends on the oil content, which constitutes the economic value of the crop. Oil makes up about 29-54\% of the dry weight of Brassica seeds (Sing and Mehta 1992) and its synthesis from sucrose constitutes one of the major metabolic activities of the embryo during seed development (Perry and Harwood 1993). Doughty et al. (1998) indicated that diseases can be significant determinants of seed oil quality via their effect on yield. In our study oil content was significantly influenced by application of fungicide only in one season (2010/2011). It coincided with the highest reduction of disease incidence following the spray with flusilazole. Experiments done by Zhou and Ye (1996) as well as Setia et al. (1996) revealed significant increases in oil content after application of uniconazole and paclobutrazole of Brassica napus and $B$. juncea, respectively. 
Table 4 Frequency (\%) of Leptosphaeria spp. species infecting oilseed rape plants in Lower Silesia (Kroscina Mala), Poland, in autumn 2009-2012 and summer 2010-2013

\begin{tabular}{|c|c|c|c|c|c|c|}
\hline \multirow[t]{2}{*}{ Season } & \multicolumn{3}{|l|}{ Autumn } & \multicolumn{3}{|l|}{ Summer } \\
\hline & L. maculans $(\%)$ & L. biglobosa $(\%)$ & Total number of isolates & L. maculans $(\%)$ & L. biglobosa $(\%)$ & Total number of isolates \\
\hline $2009 / 2010$ & 84.91 & 15.09 & 53 & 16.92 & 83.08 & 65 \\
\hline $2010 / 2011$ & 85.71 & 14.29 & 84 & 25.56 & 74.44 & 90 \\
\hline $2011 / 2012$ & 73.86 & 26.14 & 88 & 22.58 & 74.42 & 62 \\
\hline $2012 / 2013$ & 87.91 & 12.09 & 91 & 33.33 & 66.67 & 99 \\
\hline
\end{tabular}

Rapeseed meal is a source of protein for animals (Friedmann 1996). It is rich in the sulphur containing amino acids lysine, methionine and cysteine, which are limiting in cereals (Chadd et al. 2002). The seeds also contain substantial amounts of threonine. Some variation in the protein content of rapeseed can be due to cultivar, soil type and biotic and abiotic factors (Bell 1995). In our experiments, protein content of rapeseed was significantly influenced by the application of fungicides in two out of four studied seasons. The high oil content in harvested seeds after plant treatment in the autumn was significant in year of high disease pressure by $L$. maculans and L. biglobosa. The increase in oil content did not coincide with the decrease in protein content. In contrast, Doughty et al. (1998) pointed out that seeds from heavily-infected plots usually had a higher protein content. Moreover, decrease in oil content tended to be associated with increase in protein content, which suggests that the effect of disease on these two components was opposite. This observation was not supported by our study. The possible discrepancy may be related to the way of data collection; in the experiment by Doughty et al. (1998) the studies were done on selected plants, collected individually from infected or healthy plants, whereas the plant yield in our study is an average obtained for all plants growing on $15 \mathrm{~m}^{2}$ plots, irrespective of disease symptoms.

Glucosinolates are not only considered to be involved in plant defense mechanisms (Agerbirk and Olsen 2012), but also their high content impairs the quality of oil and meal. Baylis and Hutley-Bull (1991) reported that paclobutrazole reduced glucosinolates in the seeds of rapeseed significantly in comparison with untreated seeds. In our studies, fungicide treatment coincided with the increase of indole glucosinolates and reduced content of alkenyl glucosinolates. Some authors indicated that it was not a fungicide, but rather nitrogen rate, which regulated the relative proportion of alkenyl glucosinolates (Zhao et al. 1994; Zukalova et al. 2001). Further analyses are required to study whether plant treatments with fungicides can stimulate the biosynthesis of indole glucosinolates.

In our system the spray is advised after a sudden increase of the ascospore concentration in air samples,
Fig. 4 Molecular identification of Leptosphaeria maculans and L. biglobosa $\mathrm{c}$ based on the RAPD technique using the OPJ10 primer; samples from stems collected in Kroscina Mala, Poland, in the summer of 2011 are shown: PC Lm - positive control of $L$. maculans, $\mathrm{PC} \mathrm{Lb}$ - positive control of $L$. biglobosa, 1 - field isolate of $L$. maculans, $2-9$ - field isolates of L. biglobosa

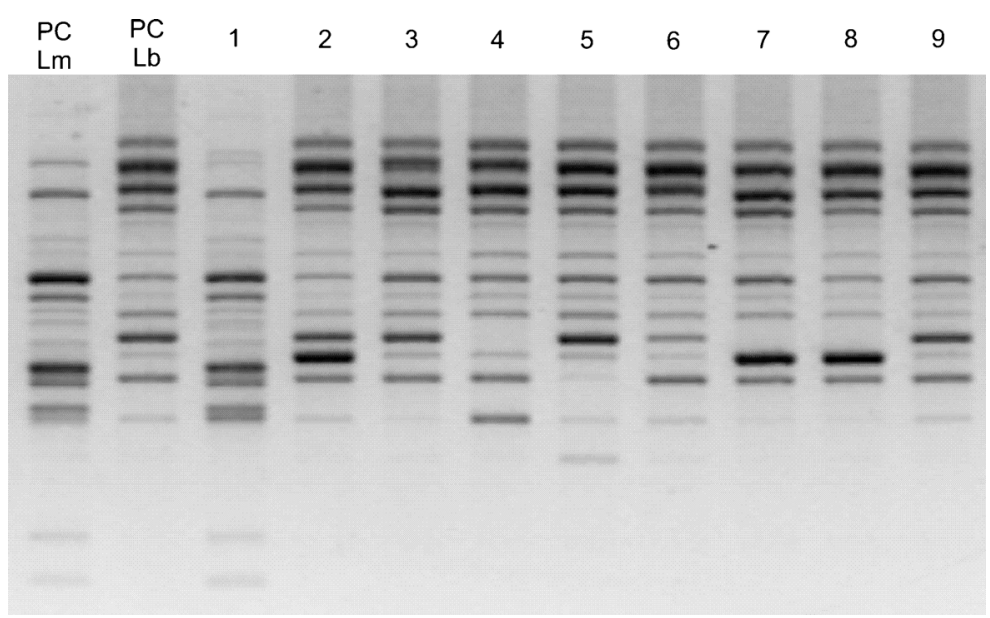


usually observed in the autumn. The minimum threshold is 10 spores per cubic meter, but this sudden rise is often a few fold higher. Also the other authors (West et al. 2009) demonstrated that the detection of primary inoculum can help to optimize the chemical protection of oilseed rape, both for the benefit of farms using a decision support system and for environment protection against inappropriate and excessive use of fungicides. This activity can be supplemented with molecular detection of DNA of L. maculans and L. biglobosa ascospores, using quantitative PCR, as presented in this paper. In general, in the autumn higher numbers of L. maculans ascospores were found as compared to L. biglobosa, which is consistent with the results of other studies on pathogen population (Kaczmarek et al. 2009). Weather in Poland has a strong effect on life cycle of the pathogen and on disease incidence and severity (Kaczmarek et al. 2015). Not all forecasts based on advanced statistical models using weather data are accurate (Jedryczka et al. 2015). However, the results of monitoring performed in Poland were used to create two well-functioning weather-based models (Improved Blackleg Sporacle and Sporacle Ezy) for predicting the onset of seasonal release of ascospores of Leptosphaeria maculans and L. biglobosa (Salam et al. 2007). SimMat, a new dynamic module of Blackleg Sporacle for the prediction of pseudothecia maturation of L. maculans/L. biglobosa species complex in different regions of Poland was elaborated (Aubertot et al. 2006) and the next module, called SimAsco is under way.

Knowledge of pathogen population structure and the ratio between the species may serve as additional tools for disease management, leading to more precise advice on the use of fungicides to protect oilseed rape against stem canker. Leptosphaeria maculans and L. biglobosa differ in their rates of spread within agricultural fields sown with winter oilseed rape and also in sensitivity to fungicides. The former species is more aggressive and it incites severe cankers at the stem base resulting in economic yield loss arising from occluded and dysfunctional vascular tissues, premature pod ripening and lodging (Williams and Fitt 1999). Lesions caused by L. biglobosa are mainly superficial necrosis on upper parts of stems. There is a controversy over the effect of this fungus on yield - it is described as rare (West et al. 2002b) or quite substantial (Jedryczka 2007).

In our studies the populations of the pathogens differed between years, but in general in the autumn
L. maculans was predominant on leaves of oilseed rape plants as it was in the air, whereas each summer L. biglobosa was predominant on stems. Differences in the timing and proportion of ascospore release in the autumn are likely to be due to differences between the species in pseudothecial maturation. Huang et al. (2007) reported that maturation of pseudothecia on the stem bases occurred 11 days earlier than that of pseudothecia on upper stem parts - associated with L. biglobosa colonisation. What is more L. maculans is able to survive burial on basal stem debris whereas L. biglobosa cannot survive on upper stem debris in dry years (Huang et al. 2007). Therefore, the burial and return of stem residues, through ploughing, may favour L. maculans. Under a minimum tillage regime both L. maculans and L. biglobosa are able to survive and produce pseudothecia on crop debris on the soil surface. If stubble is left standing after harvest, the stem base has a higher water content than upper parts of the stem (Fitt et al. 2006b). As moisture is required for pseudothecial maturation (Salam et al. 2003; Toscano-Underwood et al. 2003), therefore, ascospore release of the pathogen that has colonised the stem base will be earlier than that of the pathogen that has colonised the upper stem (Fitt et al. 2006b). On the other way, our recent experiments using oilseed rape varieties with $R \operatorname{lm} 7$ resistance genes have shown their cultivation may contribute to the increase of the population of L. biglobosa, due to great efficiency in the control of disease symptoms caused by L. maculans.

Agricultural practices such as fungicide application regime and cultivar choice are likely to affect L. maculans and L. biglobosa populations. Eckert et al. (2010) demonstrated differences between spore germination and mycelial growth of L. maculans and L. biglobosa grown on medium supplemented with fungicides. Leptosphaeria biglobosa has a lower sensitivity to azole fungicides (higher $\mathrm{EC}_{50}$, as determined by in vitro hyphal growth inhibition) than L. maculans (Eckert et al. 2004). The detection of high concentrations of the ascospores of L. biglobosa in air samples should therefore imply the application of higher doses of fungicides or fungicides with higher content of active substances. Long rotations would greatly help in controlling the disease, but they are not used by farmers, due to high profitability of the crop. Shortening of rotations have already aggravated the problem of diseases of oilseed rape. Not only has it favoured further development of blackleg, but it has also dramatically 
increased the occurrence of clubroot (Korbas et al. 2009).

Both fungal pathogens often coexist on oilseed rape plants in numerous regions and periods of time and they can accompany each other on the same host plant (Jedryczka 2007). However, there is evidence that infection by L. biglobosa may induce resistance to L. maculans. The controlled environment and field experiments have shown that pre- or co-inoculation with L. biglobosa may cause induced resistance to any subsequent infection by L. maculans (Liu et al. 2007). Due to current regulations in Poland, the doses of registered fungicides are fixed only at their maximum level and farmers cannot increase them; the new EU regulations allow to reduce dosage of fungicides based on knowledge of the composition of the current pathogen population.

Our studies confirmed that applying fungicides reduces blackleg severity, increases yield of oilseed rape and has an effect on seed quality. We have demonstrated that more precise timing of fungicide application can improve the control achieved from the fungicide use. The precision of fungicide timing can be improved by monitoring the occurrence and abundance of primary inoculum, i.e. the ascospores of fungal species of the genus Leptosphaeria, causing blackleg disease. Information on the dynamics and species composition of L. maculans and L. biglobosa in air samples and on plants may help to optimize fungicide timing and dosage.

Acknowledgments Experimental work presented in this paper was funded by the National Research Centre of Poland, project N N310 298439 and the project funded by DuPont Poland. We acknowledge Dr. Steven Strelkov, University of Alberta, Canada for his help with language and editorial amendments.

Open Access This article is distributed under the terms of the Creative Commons Attribution 4.0 International License (http:// creativecommons.org/licenses/by/4.0/), which permits unrestricted use, distribution, and reproduction in any medium, provided you give appropriate credit to the original author(s) and the source, provide a link to the Creative Commons license, and indicate if changes were made.

\section{References}

Agerbirk, N., \& Olsen, C. E. (2012). Glucosinolate structures in evolution. Phytochemistry, 77, 16-45.

Andreasson, E., Wretblad, S., Granér, G., Wu, X., Zhang, J., Dixelius, C., Rask, L., \& Meijer, J. (2001). The myrosinase-glucosinolate system in the interaction between Leptosphaeria maculans and Brassica napus. Molecular Plant Pathology, 2, 281-286.

Aubertot, J. N., Salam, M. U., Diggle, A. J., Dakowska, S., \& Jedryczka, M. (2006). SimMat, a new dynamic module of blackleg sporacle for the prediction of pseudothecia maturation of L. maculans/L. biglobosa species complex. Parameterisation and evaluation in Polish conditions. IOBC Bulletin, 29, 279-287.

Baylis, A. D., \& Hutley-Bull, P. D. (1991). The effects of a paclobutrazol based growth regulator on the yield, quality and ease of management of oilseed rape. Annals of Applied Biology, 118, 445-452.

Bell, J. M. (1995). Meal and by-product utilisation in animal nutrition. In D. Kimber \& D. I. McGregor (Eds.), Brassica oilseeds: Production and utilisation (pp. 301-337). Wallingford: CAB International.

Bliss, C. I. (1938). The transformation of percentages for use in the analysis of variance. Ohio Journal of Science, 38, 9-12.

Brazauskiene, I., \& Petraitiene, E. (2004). Disease incidence and severity of Phoma stem canker (Phoma lingam) on winter oilseed rape (Brassica napus L.) in Lithuania as affected by different prochloraz and tebuconazole application times. Journal of Plant Diseases and Protection, 115, 439-450.

Brazauskiene, I., \& Petraitiene, E. (2006). Epidemiological studies into Phoma lingam (teleomorph Leptosphaeria maculans) infections in winter and spring oilseed rape. Agronomy Research, 4, 137-140.

Chadd, S. A., Davies, W. P., \& Koivisto, J. M. (2002). Practical production of protein for food animals. Proceedings Protein Sources for the Animal Feed Industry Expert Consultation and Workshop: 77-121.

Directive 2009/128/EC of the European Parliament and of the Council of 21 October 2009 establishing a framework for Community action to achieve the sustainable use of pesticides. Official Journal of the European Union, L. 309/71.

Doughty, K. J., Norton, G., Landon, G., West, G., McCartney, H. A., Booth, E. J., Walker, K. C., Kightley, S. P. J., \& Thompson, J. E. (1998). Effects of disease on seed quality parameter of oilseed rape grown for industrial uses. H.G.C.A. Project Report, OS33, 1-44.

Eckert, M. R., Fitt, B. D. L., \& Selley, A. (2004). Leptosphaeria maculans, L. biglobosa and fungicides: preliminary results from in vitro and winter oilseed rape experiments. Integrated control in oilseed crops. International Organisation for Biological Control Bulletin, 27, 157-164.

Eckert, M., Rossall, S., Selley, A., \& Fitt, B. D. L. (2010). Effects of fungicides on in vitro spore germination and mycelial growth of the phytopathogens Leptosphaeria maculans and L. biglobosa (phoma stem canker of oilseed rape). Pest Management Science, 66, 396-405.

Fitt, B. D. L., Brun, H., Barbetti, M. J., \& Rimmer, S. R. (2006a). World-wide importance of phoma stem canker (Leptosphaeria maculans and L. biglobosa) on oilseed rape (Brassica napus). European Journal of Plant Pathology, 114, 3-15.

Fitt, B. D. L., Huang, Y. J., van den Bosch, F., \& West, J. S. (2006b). Coexistence of related pathogen species on arable crops in space and time. Annual Review of Phytopathology, 44, 163-182. 
Friedmann, M. (1996). Nutritional value of proteins from different food sources. Journal of Agricultural and Food Chemistry, 44, 6-29.

Giamoustaris, A., \& Mithen, R. (1995). The effect of modifying the glucosinolate content of leaves of oilseed rape (Brassica napus ssp. oleifera) on its interaction with specialist and generalist pests. Annals of Applied Biology, 126, 347-363.

Gladders, P., Symonds, B. V., Hardwick, N. V., \& Sansford, C. E. (1998). Opportunities to control canker (L. maculans) in winter oilseed rape by improving spray timing. International Organisation for Biological Control Bulletin, 21, 111-120.

Guo, X., \& Fernando, W. G. D. (2005). Seasonal and diurnal patterns of spore dispersal by Leptosphaeria maculans from canola stubble in relation to environmental conditions. Plant Disease, 89, 97-104.

Hammond, K. E., Lewis, B. G., \& Musa, T. M. (1985). A. systemic pathway in the infection of oilseed rape plants by Leptosphaeria maculans. Plant Pathology, 34, 557-565.

Huang, Y. J., Liu, Z., West, J. S., Todd, A. D., Hall, A. M., \& Fitt, B. D. L. (2007). Effects of temperature and rainfall on date of release of ascospores of Leptosphaeria maculans (phoma stem canker) from winter oilseed rape (Brassica napus) debris in the UK. Annals of Applied Biology, 151, 99-111.

Jedryczka, M. (2007). Epidemiology and damage caused by stem canker of oilseed rape in Poland. Phytopathologia Polonica, $45,73-75$.

Jedryczka, M., Kaczmarek, J., \& Czernichowski, J. (2006). Development of a decision support system for control of stem canker of oilseed rape in Poland. International Organisation for Biological Control Bulletin, 29, 267-278.

Jedryczka, M., Plachka, E., Kaczmarek, J., Poslusna, J., \& Maczynska, A. (2010). Monitoring of Leptosphaeria maculans and L. biglobosa ascospores around East Sudethian mountains - a joint initiative of Poland and the Czech Republic. Rośliny Oleiste - Oilseed Crops, 31, 49-66.

Jedryczka, M., Brachaczek, A., Kaczmarek, J., Dawidziuk, A., Kasprzyk, I., Maczynska, A., Karolewski, Z., Podlesna, A., $\&$ Sulborska, A. (2012). System for Forecasting disease epidemics (SPEC) - decision support system in Polish agriculture, based on aerobiology. Alergologia Immunologia, 9, 89-91.

Jedryczka, M., Strzelczak, A., Grinn-Gofron, A., Nowak, M., Wolski, T., Siwulski, M., Sobieralski, K., \& Kaczmarek, J. (2015). Advanced statistical models commonly applied in aerobiology cannot accurately predict the exposure of people to Ganoderma spore-related allergies. Agricultural and Forest Meteorology, 201, 209-217.

Kaczmarek, J., \& Jedryczka, M. (2011). Characterization of two coexisting pathogen populations of Leptosphaeria spp., the cause of stem canker of brassicas. Acta Agrobotanica, 64, $3-$ 14.

Kaczmarek, J., Jedryczka, M., Fitt, B. D. L., Lucas, J. A., \& Latunde-Dada, A. O. (2009). Analyses of air samples for ascospores of Leptosphaeria maculans and L. biglobosa with light microscopic and molecular techniques. Journal of Applied Genetics, 50, 411-419.

Kaczmarek, J., Jedryczka, M., Cools, H., Fitt, B. D. L., Lucas, J. A., \& Latunde-Dada, A. O. (2012). Quantitative PCR analysis of abundance of airborne propagules of Leptosphaeria species in air samples from different regions of Poland. Aerobiologia, 28, 199-212.

Kaczmarek, J., Brachaczek, J., \& Jedryczka, M. (2014). The effect of fungicide spray time on the incidence of stem canker of brassicas and seed yield of winter oilseed rape in Pomerania. Journal of Plant Diseases and Protection, 121, 58-63.

Kaczmarek, J., Kedziora, A., Brachaczek, A., Latunde-Dada, A. O., Dakowska, S., Karg, G., \& Jedryczka, M. (2015). Effect of climate change on sporulation of the teleomorphs of Leptosphaeria species causing stem canker of brassicas. Aerobiologia. doi:10.1007/s10453-015-9404-4.

Karolewski, Z., Wachowiak, M., Ratajkiewicz, H., \& Kierzek, R. (2009). Effect of adjuvants, spray volume and nozzle type on metconazole activity against Leptosphaeria biglobosa and $L$. maculans during late spring treatments in winter oilseed rape. Journal of Plant Protection Research, 49, 113-117.

Kjeldahl, J. Z. (1883). A new method for the determination of nitrogen in organic bodies. Analytical Chemistry, 22, 366.

Korbas, M., Jajor, E., \& Budka, A. (2009). Clubroot (Plasmodiophora brassicae) - a threat for oilseed rape. Journal of Plant Protection Research, 49, 446-451.

Lacey, M. E., \& West, J. S. (2006). The air spora - A manual for catching and identifying airborne biological particles. Dordrecht: Springer.

Liu, S. Y., Liu, R. H., Latunde-Dada, A. O., Cools, H. J., Foster, S. J., Huang, Y. J., \& Fitt, B. D. L. (2007). Comparison of Leptosphaeria biglobosa -induced and chemically induced systemic resistance to Leptosphaeria maculans in Brassica napus. Chinese Science Bulletin, 52, 1053-1062.

Lô-Pelzer, E., Aubertot, J. N., Bousset, L., Pinochet, X., \& Jeuffroy, M. H. (2009). Phoma stem canker (Leptosphaeria maculans/L. biglobosa) of oilseed rape (Brassica napus): is the G2 disease Index a good indicator of the distribution of observed canker severities? European Journal of Plant Pathology, 125, 515-522.

Luque de Castro, M. D., \& García-Ayuso, L. E. (1998). Soxhlet extraction of solid materials: an outdated technique with a promising innovative future. Analytica Chimica Acta, 369, $1-10$.

Mahuku, G. S., Hall, R., \& Goodwin, P. H. (1996). Co-infection and induction of systemic acquired resistance by weakly and highly virulent isolates of Leptosphaeria maculans in oilseed rape. Physiological and Molecular Plant Pathology, 49, 6172.

Manici, L. M., Lazzeri, L., \& Palmieri, S. (1997). In vitro fungitoxic activity of some glucosinolates and their enzyme-derived products toward plant pathogenic fungi. Journal of Agricultural and Food Chemistry, 45, 2768-2773.

Michalski, K., \& Czernik-Kolodziej, K. (2000). Application of NIR spectrometry for analysis of basic chemical constituents of rapeseed seeds. Rośliny Oleiste-Oilseed Crops, 21, 801807.

Peng, G., Kirkham, C., Fernando W. G. D., Lange, R., McLaren, D. L., Kutcher, H. R., Johnson, E. N., \& Turkington, T. K. (2015). Early fungicide application reduces blackleg impact on canola only when cultivar resistance is broken and the disease pressure is high. 14th International Rapeseed Congress, Saskatoon, Canada, 5-9 July 2015. Abstract book: 107. 
Perry, H. J., \& Harwood, J. L. (1993). Changes in the lipid content of developing seeds of Brassica napus. Phytochemistry, 32, 1411-1415.

Piliponyte-Dzikiene, A., Kaczmarek, J., Petraitiene, E., Kasprzyk, I., Brazauskiene, I., Brazauskas, G., \& Jedryczka, M. (2014). Microscopic and molecular detection of airborne ascospores of Leptosphaeria maculans and L. biglobosa in Lithuania and Poland. Zemdirbyste-Agriculture, 101, 303-312.

Sáez-Plaza, P., Navas, M. J., Wybraniec, S., Michalowski, T., \& Asuero, A. G. (2013). An overview of the Kjeldahl method of nitrogen determination. Part II. Sample preparation, working scale, instrumental finish, and quality control. Critical Reviews in Analytical Chemistry, 43, 224-272.

Salam, M. U., Khangura, R. K., Diggle, A. J., \& Barbetti, M. J. (2003). Blackleg sporacle: A model for predicting onset of pseudothecia maturity and seasonal ascospore showers in relation to blackleg of canola. Phytopathology, 93, 10731081.

Salam, M. U., Fitt, B. D. L., Aubertot, J.-N., Diggle, A. J., Huang, Y. J., Barbetti, M. J., Gladders, P., Jedryczka, M., Khangur, A. R. K., Wratten, N., Fernando, W. G. D., Pinochet, X., Penaud, A., \& Sivasithamparam, K. (2007). Two weatherbased models for predicting the onset of seasonal release of ascospores of Leptosphaeria maculans or L. biglobosa. Plant Pathology, 56, 412-423.

Setia, R. C., Kaur, P., Setia, N., \& Anuradha (1996). Influence of paclobutrazol on growth and development of fruit in Brassica juncea (L.) Czern and coss. Plant Growth Regulation, 20, 307-316.

Sing, S. P., \& Mehta, S. L. (1992). Manipulation of oil quantity and quality in annual oilseed crops. Journal of Oilseeds Research, 9, 97-118.

Steed, J. M., Baieri, A., \& Fitt, B. D. L. (2007). Relating plant and pathogen development to optimise fungicide control of phoma stem canker (Leptosphaeria maculans) on winter oilseed rape (Brassica napus). European Journal of Plant Pathology, 118, 359-373.
Sun, P., Fitt, B. D. L., Gladeders, P., \& Welham, S. J. (2000). Relationships between phoma leaf spot and development of stem canker (Leptosphaeria maculans) on winter oilseed rape (Brassica napus) in Southern England. Annals of Appied Biology, 137, 113-125.

Toscano-Underwood, C., Huang, Y. J., Fitt, B. D. L., \& Hall, A. M. (2003). Effects of temperature on maturation of pseudothecia of Leptosphaeria maculans and L. biglobosa on oilseed rape stem debris. Plant Pathology, 52, 726-736.

West, J. S., Fitt, B. D. L., Leech, P. K., Biddulph, J. E., Huang, Y.J., \& Balesdent, M.-H. (2002a). Effects of timing of Leptosphaeria maculans ascospore release and fungicide regime on phoma leaf spot and phoma stem canker development on winter oilseed rape (Brassica napus) in Southern England. Plant Pathology, 51, 454-463.

West, J. S., Balesdent, M. H., Rouxel, T., Narcy, J. P., Huang, Y. J., Roux, J., Steed, J. M., Fitt, B. D. L., \& Schmit, J. (2002b). Colonization of winter oilseed rape tissues by $\mathrm{A} / \mathrm{Tox}(+)$ and $\mathrm{B} /$ Tox(0) Leptosphaeria maculans (phoma stem canker) in France and England. Plant Pathology, 51, 311-321.

West, J. S., Atkins, S. D., \& Fitt, B. D. L. (2009). Detection of airborne plant pathogens; halting epidemics before they start. Outlooks on Pest Management, 20, 11-14.

Williams, R. H., \& Fitt, B. D. L. (1999). Differentiating A and B groups of Leptosphaeria maculans, causal agent of stem canker (blackleg) of oilseed rape. Plant Pathology, 48, 161-175.

Zhao, F. J., Evans, E. J., Bilsborrow, P. E., \& Syers, J. K. (1994). Influence of nitrogen and sulphur on the glucosinolate profile of rapeseed (Brassica napus L). Journal of the Science of Food and Agriculture, 64, 295-304.

Zhou, W., \& Ye, Q. (1996). Physiological and yield effects of uniconazole on winter rape (Brassica napus L.). Plant Growth Regulation, 15, 69-73.

Zukalova, H., Matula, J., Kuchtova, P., \& Miksık, V. (2001). Effect of sulfur on the yield and quality of winter oilseed rape. Rośliny Oleiste - Oilseed Crops, 22, 587-596. 